\title{
A Rare case of bear attack on the face and the treatment in college of medical sciences, Bharatpur, Central Nepal
}

\author{
Dr. Ashutosh Kumar Singh ${ }^{1}$, Dr. Sanad Dulal ${ }^{1}$, Dr. N. Jayaprakasha Mayya ${ }^{2}$ \\ ${ }_{1}^{1}$ Department of Oral \& Maxillofacial Surgery, ${ }^{2}$ Department of ENT \& HNS, College of Medical \\ Sciences, Bharatpur, Nepal
}

\begin{abstract}
Correspondence
Dr. Ashutosh Kumar Singh,

Dept of Oral and

Maxillofacial surgery,

College of Medical Sciences,

Bharatpur, Nepal.

Email:

drashutoshkumarsingh@gmai $1 . \mathrm{com}$
\end{abstract}

DOI: http://dx.doi.org/10.3126/ jemsn.v11i2.13674

\begin{abstract}
This case report presents a case of wild bear attack in the central region of Nepal causing extensive maxillofacial injuries and its management. The patient suffered bilateral comminuted midface fractures with extensive soft tissue lacerations. Management included multidisciplinary approach including maxillofacial surgeons, ENT surgeons and cosmetic surgeon to realign the injured soft tissue and bone to pre injury state. Outcome was satisfactory given the initial presentation of patient
\end{abstract}

Key words: Bear attack, bilateral comminuted midface fracture, maxillofacial surgery

Citation: Singh AK, Dulal S, Mayya J. A Rare case of bear attack on the face and the treatment in college of medical sciences, Bharatpur, Central Nepal. JCMS Nepal. 2015;11(2):31-33.

\section{INTRODUCTION}

Bear attack on the face and neck is a rare event causing a lot of injury to the neck and face, disfigurement and other life threatening consequences. The earliest form of surgical treatment would involve evaluation of vitals and early tracheostomy to secure the airway if urgently required followed by repair of primary injuries involving the face and throat. In the presented case, the second sitting surgical correction in the form of reconstruction of nasal dorsum was done by harvesting costo-chondral cartilage from the rib. The complete procedure was undertaken by a team of Oral and maxillofacial surgeons, ENT surgeon and cosmetic surgeon.

\section{CASE REPORT}

A fifty-five year male patient presented in the emergency department of COMS-TH on 4th February 2015 with history of bear attack on the morning at $10 \mathrm{am}$ when he had left from jungle, following which there was profuse bleeding from mouth and face and severe lacerations were present on maxillofacial region. One episode of vomiting after arrival to the hospital was noted. No History of seizure attack or neurological deficits was noted. On local examination there was gross injury over face involving the nose, left maxilla and left eye. On examination of ear, right pinna was lacerated, cartilage exposed, tympanic membrane not visualized.
Investigations like non contrast computed tomography (NCCT) brain with bony window and 3D face showed multiple fractures of bilateral maxilla, all the walls of bilateral maxillary sinuses, right zygomatic arch, bilateral zygoma, lateral wall of bilateral orbits, bilateral nasal bone and nasal septum. Soft tissue swelling with air pockets was noted involving almost the entire face. Collection noted in bilateral maxillary sinuses, ethmoid air cells, sphenoid sinus, bilateral nasal cavity and nasopharynx. All the required basic investigations were done including chest $\mathrm{x}$-ray, cervical spine, ECG were normal, but hemoglobin $(\mathrm{Hb})$ level was $5.9 \mathrm{gm} / \mathrm{dl}$.

\section{PROCEDURES DONE:}

Based on the above presentation in the ER, one unit of whole blood was transfused and debridement, suturing and tracheostomy was done under general anaesthesia in the first sitting on 4th Feb 2015. A vertical incision was given for tracheostomy and 7.5 Portex cuffed tracheostomy tube was inserted. A Foley's catheter was used as posterior nasal packing to control bleeding. Nasogastric tube was inserted for the feeding.

Arch bars and stainless steel wires were used to realign the fractured maxilla and palate following which the zygomatic bones and orbital walls were aligned using 26 gauze stainless steel wires to perform an internal wire fixation as a temporary means to achieve a somewhat symmetrical pre injury state of bones over which soft tissue could be 
repaired .Final fixation of facial bones was planned as a secondary procedure.

Patient was kept under observation in intensive care unit and followed up. Again on 12th Feb 2015 under general anesthesia following procedures were performed:

1. Open reduction and internal fixation (ORIF) of all maxillary bones were done using intraoral approach as well as existing lacerations. Occlusion was achieved with arch bars and wires. Fixation was done using $2 \mathrm{~mm}$ miniplating system at the Le-fort I level and orbital rim.

2. Reconstruction and grafting of nasal bone done with costochondral cartilage. The rib graft was harvested from 5th costochondral cartilage (CCG).

3. All the injuries were sutured with 5-0 prolene. Patient was again given blood transfusion and his $\mathrm{Hb}$ improved to $12.2 \mathrm{gm} / \mathrm{dl}$ and platelet: $2,70,000 / \mathrm{mm} 3$. Rabies vaccine was also given as per schedule.

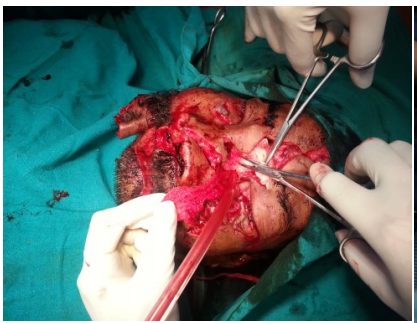

Fig 1a. Severe laceration of maxillofacial region

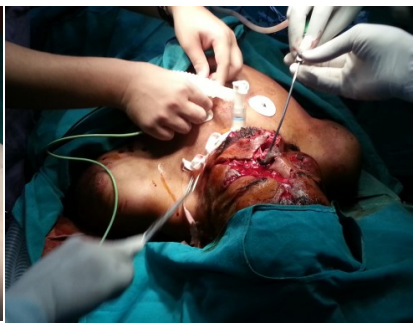

Fig 1b. Immediate tracheotomy

\section{DISCUSSION}

Facial bone injuries by the attack of wild animals are quite rare and potentially dangerous. The incidence of bear maul attacks is on a rising trend since the last 6-7 years and more attacks have occurred near foothills and villages which are

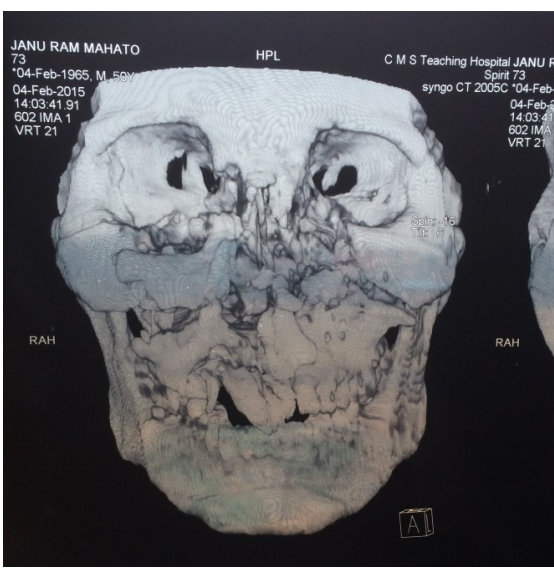

Fig 1c: Pre operative NCCT face with 3D reconstruction showing communited and displaced maxillary, palatal and zygomatic bone fractures . populated areas, rather than in the forests. This depicts migration of bears from forest areas toward the more populated areas. One of the reasons for bear migration could be deforestation of the

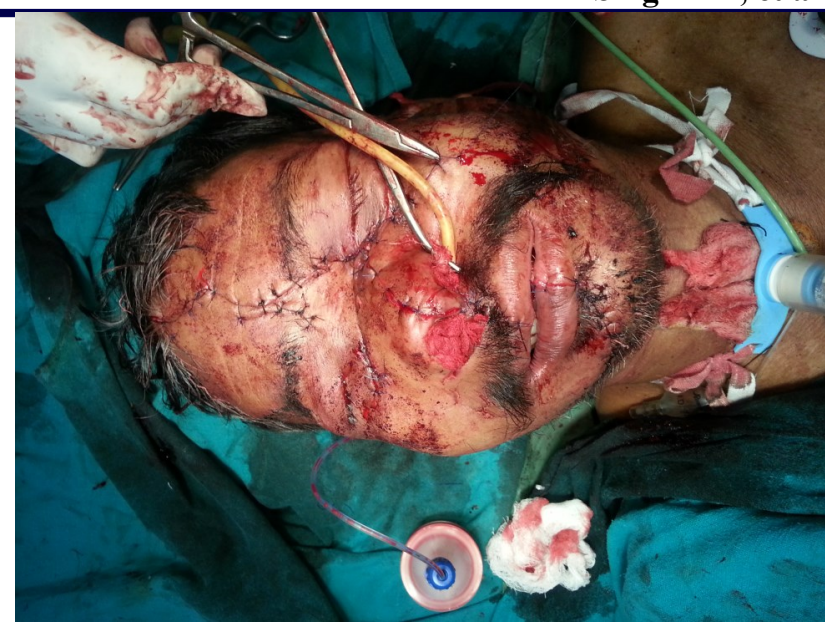

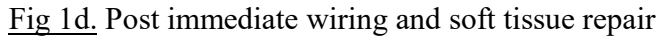

thereby the bears move down toward foothills, villages and towns. Injuries by bears were studied by Middaugh between 1900 and 1985,1 who also noted a rising trend during later period of his study which he attributed to rise in population and increase in tourism. Most of the case reports of bear maul injuries, as reported in the literature, belong to face and head only.2-7 Predominance of head and

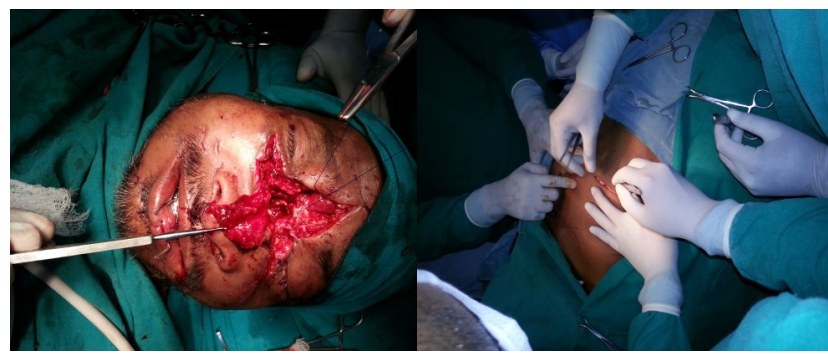

Fig 2a. Maxillofacial bone fracture plating and CCG harvest

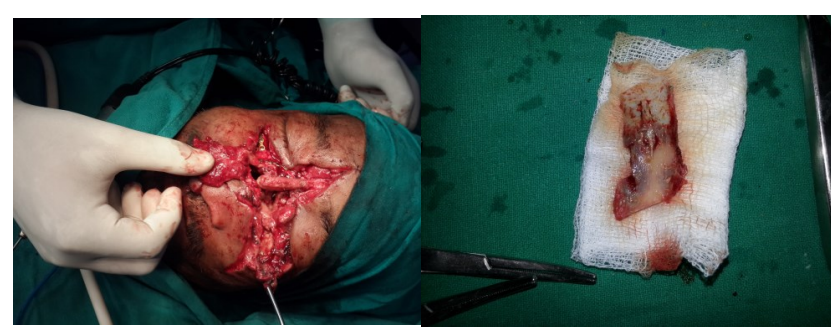

Fig 2b. Nasal Dorsum reconstruction using CCG
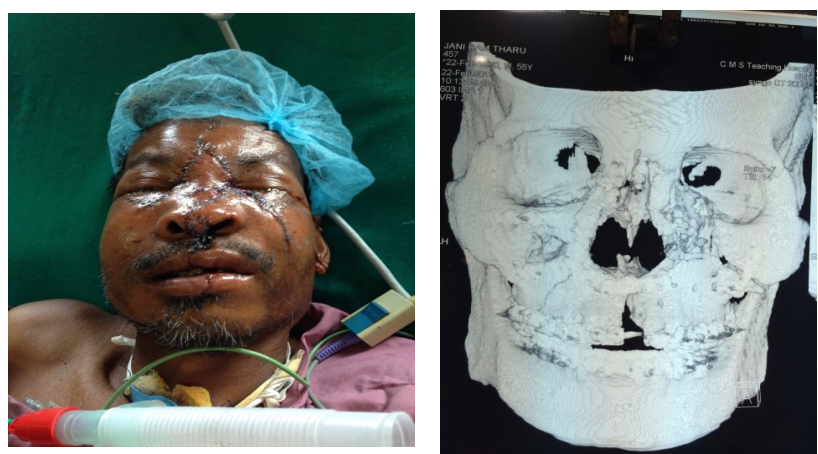

Fig 2c. Patient recovering in ICU after second surgery and post -operative CT showing excellent maxillofacial bone reduction and nasal dorsal reconstruction 


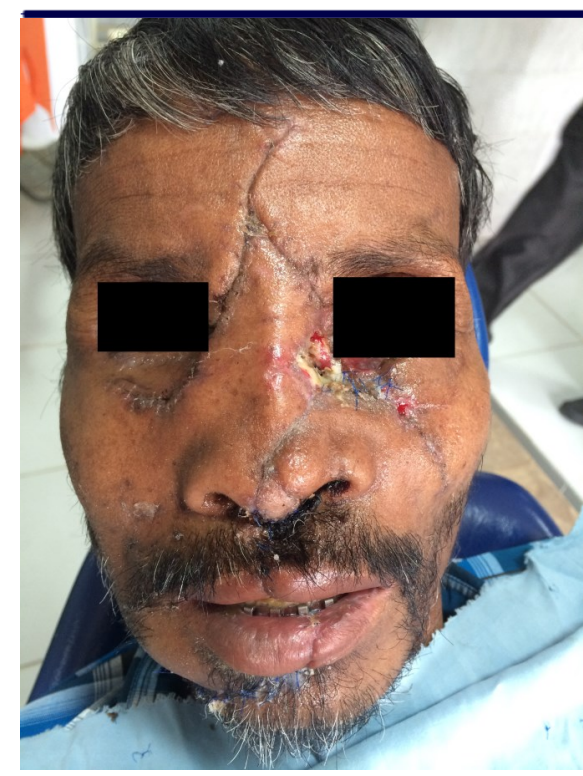

Fig 2d. Follow up one month after surgery facial injuries in bear mauling can be explained on the basis that head and face are the most prominent parts of body and there being multiple irregularities over the face due to bony projections, makes these parts easily available for bears paws/ claws, resulting in severe injuries. Secondly, bears being highly intelligent animals, try to weaken their enemy by easily targeting their face so that they are unable to fight back and harm them.

Initial management of this case with tracheostomy and debridement, suturing and interdental wiring with blood transfusion and intensive care unit management was done promptly on the Day 1 and followed up.

One week later reconstructive procedure under general anesthesia with ORIF and nasal bone graft from costochondral cartilage was done and patient was kept in intensive care unit for further management.

\section{CONCLUSION}

We report here a case of rare bear attack on the face and neck which was managed with a combined team effort of maxillofacial surgeon, ENT surgeon and cosmetic surgeon.

\section{ACKNOWLEDGEMENTS:}

We thank the management of College of medical sciences, all of our residents, operation theatre staffs and other assistants for their excellent support.

\section{REFERENCES}

1. Middaugh JP .Human injury from bear attacks in Alaska, 1900-1985. Alaska Med. 1987 Sep-Oct; 29(4):121-6

2. Venkataswami G, Rajagopalan AV. A case of injury of right eye by a bear. J All India Ophthalmol Soc. 1962;10:22-3.

3. Govilla A, Roa GS, James JH. Primary reconstruction of major loss of lower jaw by an animal bite using a "Rib sandwich" Pectoralis Major Island flap. Br J PI Surg. 1989;42:101-3.

4. Hayashi Y, Fujisawa H, Tohma Y, Yamashita J, Inaba H. Penetrating head injury caused by bear claws: Case report. J Trauma. 2003;55:1178-80.
5. Kunimoto D, Rennie R, Citron DM, Goldstein EJ. Bacteriology of a bear bite wound to a human: Case report. J Clin Microbiol. 2004;42:3374-6.

6. Vougiouklakis T. Fatal brown bear (Ursus Arctos) attack: Case report and literature review. Am J Forensic Med Pathol. 2006;27:266-7.

7. Jethani J, Nagori R, Ghodadara B. An unusual case of bear bite with severe loss of tissue. Indian $\mathrm{J}$ Ophthalmol. 2006;54:287-8. 